\title{
The Policy of Minimarket Business Control in Semarang City
}

\author{
Devi Nur Puspitasari; Ari Subowo; Sri Suwitri \\ Faculty of Socialand Politic Sciences \\ Diponegoro University \\ Semarang, Indonesia \\ (Office Email: prodidap@gmail.com)
}

\begin{abstract}
Urban areas have a great chance to develop the economy in terms of trade, services and businesses. The growth of economic is followed by an increase in public consumption and the availability of business space which can be reached easily and close to the residential area. The closeness of minimarket In Semarang has made it easier for consumers to meet daily needs is required, thus providing an opportunity for entrepreneurs to control the modern retail market. Also, it could be found there is a tough competition two renowned brands ie Alfamart and Indomaret. The strategies of marketing concept to attract consumers by a very similar design as well as location tend to be near even several units side by side and face to face. Therefore, it should be hold of an arrangement or control businesses minimarket to maintain a balance between the modern market with traditional markets or micro businesses.
\end{abstract}

Keywords—Business Control; Minimarket; Modern Market

\section{INTRODUCTION}

Characteristics of community life in the urban area are living in nonagrarian. City functions become more dominant and unique is in the cultural, industry, services, and trade. Interaction and interrelation of the most prominent urban communities marked by activities are economical and commerce. Within the last few years modern store business is very tempting to be lived. Orientation of the consumer spending that previously only the pursuit of low prices and now conforness is consumer's priority. Types of modern stores that are trending among the community is a minimarket. With a lot of outlets of minimarket will potentially to change the way consumers view in determining of shopping destination. Minimarket business grows rapidly across Indonesia from the city to the sub-districts. In this case as well, the city of Semarang have progressing fairly rapid establishment to minimarket. According to data compiled by the Regional Development Planning Agency, the spread of modern market / modern stores in Semarang in 2010 there are 244 minimarket spread in 16 sub-districts. (http://bappeda.semarang.PolaPerpasaran/publikasi.go.id/uploaded/.pdf). The existence of the modern store if left will affect the position of the small business that pressed by inbalance competition.

\section{RESEARCH METHOD}

The policy research is using qualitative research methods are intended to identify government policy in controlling minimarket in Semarang and analyze the factors that emerged as a result of the implementation of the policy. Data collection techniques used in this research is by observation, interviews and document research.

\section{RESUlt AND Discussion}

Semarang city is the administrative center in the province of Central Java who has a big influence on the climate investment. On one hand the existence of minimarket could affect the existence of shops/stalls preexisting, but also unavoidable that with the investor is able to increase local revenue Semarang City. Therefore, to overcome the problem of the spread of the existence of minimarket establishments in the city, the government issued regulations to control the minimarket business establishment in the city of Semarang set by Mayor Regulation No. 5 In 2013 about Structuring Modern Stores Minimarket. In it regulates the quota restrictions on the establishment of minimarket in each district by using modern store business license (IUTM).

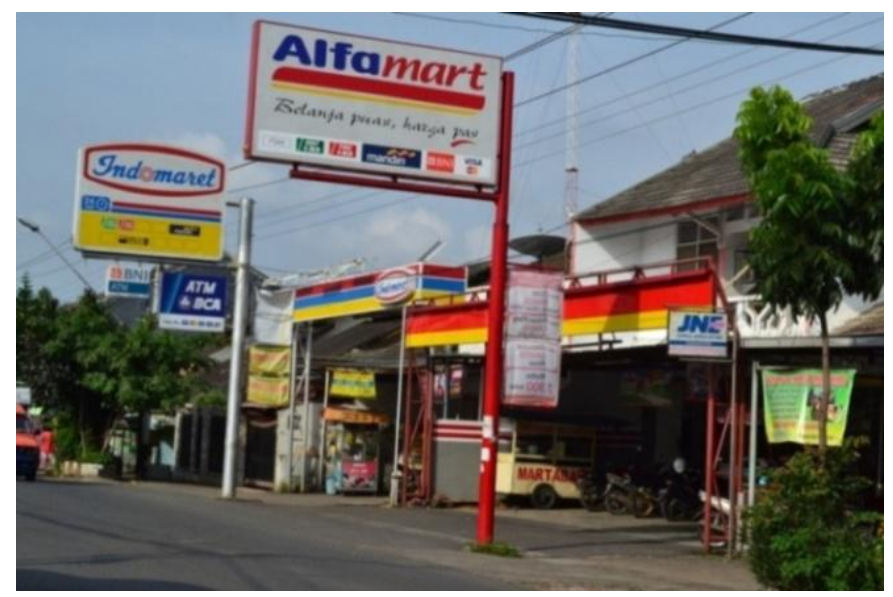




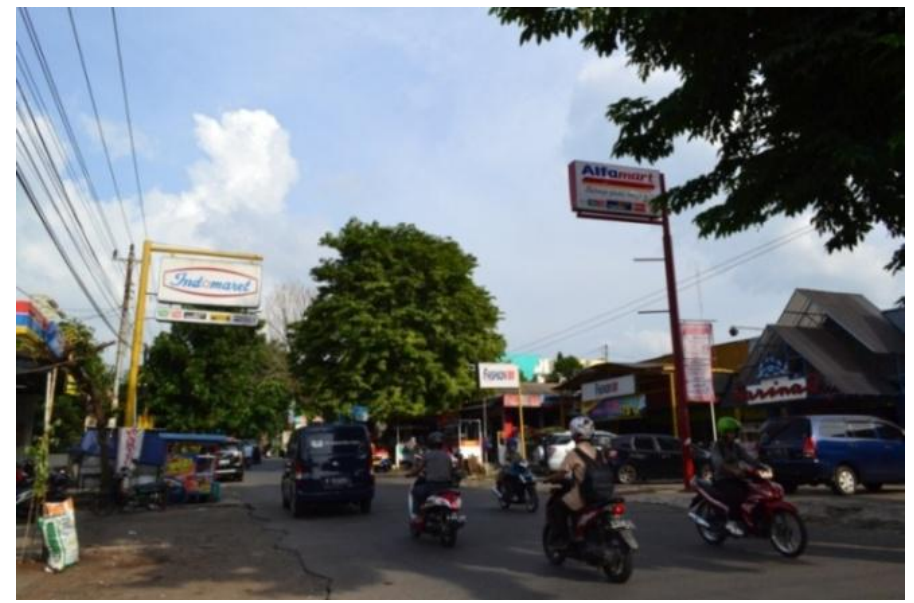

Source : Documentation by Devi Nur Puspitasari, 2015

Fig. 1. The layout of the minimarket in Semarang City

The Policy of Business Control Minimarket in Semarang experienced some problems which are:

\section{A. Unlicense Minimarket}

Based on data collected by Badan Pelayanan Perijinan Terpadu (BPPT) Semarang City, until 2014 had issued 140 IUTM with the greatest number are in Sub Banyumanik. It has 20 IUTM with a quota of a maximum number of 52 license. But in reality, it can be found more than 20 minimarket that operated in the sub-district of Banyumanik. As presented in the Journal of Geodesy UNDIP April 2015 edition of the Study of Distribution and Potential Minimarket Based SIG that based on survey results minimarket is not only built on the main roads, but also on local roads. In the sub-district Banyumanik it already built 32 mini. This shows that in Sub Banyumanik there are still some minimarket that does not have a business license (Devi, 2016: 103).

\section{B. Establishment location}

Some minimarket not notice the existence of traditional markets or small shops around the establishment of their buildings. Such as in the Market Rasamala, minimarket should stand on a radius of at least 500 meters from traditional markets but the distance with the minimarket is less than 200 meters. In this case the government does not act decisively because they provide an opportunity for entrepreneurs to spend a building contract and then did a relocation.

\section{The penalty is only administrative penalty}

Minimarket that do not comply with the provisions in accordance with the existing regulations will be penalized. During this time the sanctions provided by the government only in the form of administrative penalty such as written warning, freezing, license revocation and closure of business premises. These penalties are less powerful to against further offenses committed by businesses because of administrative penalty heaviest simply closing places of business to never do any trade for 3 months, after that minimarket can take care of their business license back.

\section{CONCLUSION}

It is undeniable that the existence of minimarket becomes a style of consumption nowdays. Convenience, comfort and innovations captivate and has its own appeal compared to shopping at traditional markets. Actually the existence of minimarket is developmental progression, so in this case minimarket business operators are not entirely wrong. The level of willingness of the government to revitalize traditional markets into a comfortable place and enthused by the community becomes a task and challenge to keep minimarket balance. As longer the traditional market has good management, the consumers will always have interest in traditional market. In addition the creation of innovation vend for micro enterprises is also needed to develop, so the traditional market can compete with the minimarket, not only in terms of appearance but also the service. So it be better if the relationship between stakeholders stable and mutually supportive, then the goal to improve the economy is could be controlled.

\section{REFERENCES}

[1] Ma'aruf, Hendri. (2008). Pemasaran Ritel. Jakarta : Gramedia Pustaka Utama

[2] Mohammad Mukti Ali, Samsuk Ma'rif, dan Rizki Kirana Yuniartanti. (2014). Jurnal Pembangunan Kota Semarang Berbasis Sains \& Teknologi. Jurnal. Bappeda Kota Semarang. Riptek Vol. 8, No. 2, Tahun 2014, Hal. 61-82

[3] Pontoh, Nia K dan Iwan Kustiawan. (2009). Pengantar Perencanaan Perkotaan. Bandung : ITB

[4] Peraturan Walikota Semarang Nomor : 15 Tahun 2013 tentang Penataan Tata Ruang Toko Modern Minimarket di Kota Semarang

[5] Puspitasari, Devi Nur. (2016). Penataan Tata Ruang Minimarket di Kecamatan Banyumanik Kota Semarang (Studi Implementasi tentang Peraturan Daerah Kota Semarang No. 1 Tahun 2014). Skripsi. Universitas Diponegoro 